\title{
The Legacy: Opportunities from Colonialism
}

As one story draws to an end, another unfolds. Now that Hāmida Bībī failed to achieve what she wanted, it was the turn of Nāzira Bībī, the first wife of the deceased Muhammad Riḍā Bāy, to attempt to squeeze money from the qã Muhỵi al-Dīn Khwāja. In 1898, Nāzira Bībī must have been one of the most frequent appellants to the chancellery of the Tashkent city commandant and the military governor of Syr-Darya province. Six times she denounced the supposed malpractices of that qā $\bar{\imath} \bar{\imath}$ in matters of guardianship. Her story was a common one. After the death of her husband, Nāzira Bībī was appointed guardian of her underage children, daughter Anzirat Bībī and mentally disabled (ma'tūh) son Hāshīm Jān. She was supposed to supervise the wealth they inherited from their deceased father, the considerable sum of more than 28,00o rubles. This sum was deposited in the Tashkent branch of the state bank in 1896. That same year, Nāẓira Bībī's daughter Anzirat Bībī married a certain Mullā 'Abd al-Wahhāb Iunusbaev, but Anzirat Bībī soon died, and her estate had to be divided between her mother and her husband.

The two parties met half way, agreeing that Iunusbaev was entitled to a share valued at 3,063 rubles. But transferring this money became a problem, because the bank required that the $q \bar{a} d \bar{\imath}$ issue a simple certificate establishing that Iunusbaev was entitled to a share of the estate of which Nāẓira Bībì was the guardian. The judge, Muhyī al-Dīn Khwāja, refused to issue the certificate, being adamant that Nāzira Bībī had failed to submit a report about her activity as guardian in the year 1897 and that he would issue no document until he received one. This was the event that triggered all of Nāzira Bībī's complaints.

A Muslim judicial assembly assessed the conflict and decided that Muhyi al-Dīn Khwāja must provide the certificate required and Nāzira Bībī the missing report. Although he gave the woman the documents she needed, the bank would not give her the money, because the certificate she presented did not state from which share the sum should be taken. Nāzira Bībī's attorney, a Russian by the name of Karacharov, pleaded that the Tashkent city commandant order Muhyī al-Dīn Khwāja amend the certificate. The qāọ̄ did craft a new document for Iunusbaev, but the commandant found it inappropriate. The Russian officer returned the paper to the Muslim judge with the request that he explain his ill-judged behavior. Muhyī al-Dīn Khwāja replied to the commandant that the document was sound, because Iunusbaev alone was entitled to receive the money from the bank, whereas the wealth Nāzira Bībì 
and her son had inherited had to remain in the bank, at least as long as Nāzira Bībī failed to provide an account of her activities as guardian in 1897.

Things were getting complicated now, because Nāzira Bībỉs appeals were producing their effect. She approached Russian authorities, depicting the $q \bar{a} d \bar{l}$ as displaying personal hostility and inequitable conduct (nepravil'nye deistviia). ${ }^{1}$ She hammered into the bureaucrats that her relations with the $q \bar{a} d \bar{\imath}$ were inimical (vrazhdebnye otnosheniia) ${ }^{2}$ and that he was abusing his authority (prevyshaet svoiu vlast'). ${ }^{3}$ Her appeals finally paid off when she was able to convince Lieutenant Aleksei Fok, assistant to the Tashkent city commandant. On two occasions Fok wrote to the state bank. The first time, he argued the sum in question should be paid to Nāzira Bībī simply because she was the guardian of the minors' property held in the account. The second time, Fok took a more legalistic tone, referring to the 1897 regulation that stated that native judges should transfer the property of minors to the banks if they were unable to appoint a suitable guardian of the property or lend the money at a profitable rate. Fok wrote:

This means that the guardian [Nāzira Bībī] has the full right to take from the bank the minors' money; [this also means] that the refusal of the bank [to pay her...] should be ignored. ${ }^{4}$

Fok was urging the bank to pay out to Nāzira Bībī, warning that a new refusal would lead him to complain directly to the governor-general. The bank replied that Fok's behavior raised a conflict of jurisdiction: ${ }^{5}$ the bank had ignored the new 1897 provision and simply relied on the statutory law, under which native judges oversaw all civil cases among the indigenous population. Were the $q \bar{a} d \bar{\imath} \mathrm{s}$ alone to deal with issues of guardianship, or were they not? And, the bank asked, did Fok's notifications have any legal bearing? Fok appeared to be siding with Nāzira Bībī, and, indeed, he dared to write a note directly to the governorgeneral charging Muhȳī al-Dīn Khwāja with disobeying his orders to issue the required certification.

1 Nāzirira Bībī to the governor-general, 10.07.1898, TsGARUz, f. I-17, op. 1, d. 6366, l. 36ob.

2 Nāzira Bībī to the city commandant, 10.04.1898, ibid.: ll. 1, 5ob (15.05.1898), and 24ob (25.06.1898); Nāẓira Bībī to the military governor, 19.06.1898, ibid.: 1. 23; Nāẓira Bībī to the governor-general, 10.07.1898, ibid.: 1. 36 .

3 Ibid.: 1. 5ob.

4 City commandant to the state bank, 17.07.1898, ibid.: 1l. 30-30ob.

5 State bank (Tashkent section) to the military govenor, 24.07.1898, ibid.: l. 28. 
Fok also tried to bring to the attention of the head of the colonial government the fact that Muhyī al-Dīn Khwāja had already been investigated several times for malpractice and that the Tashkent city commandant had, on one occasion, requested that he be removed from his post. Fok also emphasized that witnesses had substantiated several accusations against the $q \bar{a}$ d $\grave{\imath}$ but that the provincial chancellery had dropped all the charges against him. In other words, Fok was claiming that, like him, the city chancellery was seeing things that the provincial chancellery had overlooked. Asked to report on the personal initiative he had taken, he explained that he was relying on the judgment of other native judges who agreed that Nāzirira Bībī was entitled to the money. He was also expressing his personal view of the $q \bar{a} d \bar{t}$, which he felt deserved the governor-general's attention, though it diverged substantially from the view of the provincial chancellery.

Though Fok was actively supported by his superior, the city commandant, ${ }^{6}$ the pressure exerted by the provincial chancellery proved overwhelming: the bureaucrats of Syr-Darya Province felt that Fok had accused them of covering up the misconduct of the qādi (kak by ukryvaet bezzakonnie deistviia kaziia) and dropping charges against him in the face of clear evidence. ${ }^{7}$ Fok was made liable for insubordination due to a turf war between two bureaucratic levels, one trying to bolster its authority by casting a shadow over the activities of the other.

There is, however, a different story here, of continuity in the opinions expressed and of the measures the Tashkent city commandants and their assistants subsequently undertook to restrict the authority of the qā of the guardianship of minors' property. It was Lykoshin who suggested that minors' money be taken from the qä $\overline{d i s}$ and deposited in banks. This had happened in 1892, when he was instructed to inquire into the claims of embezzlement of minors' money that involved Muhỵi al-Dīn Khwāja. Seven years later, it was Fok who infringed on the activities of the $q \bar{a} d \bar{l}$ in matters of guardianship. He sided with Nāzira Bībī in what he saw as a case of Muslim judicial neglect.

The story of Nāzira Bībi offers a starting point for recapitulating some of the themes addressed in Visions of Justice and reflecting on the simplistic nature of the compliance/resistance paradigm that has so far informed our understanding of Central Asian colonial history. Russian rule in the region was based on the purported preservation of traditions that were integral to the regional Islamic legal culture. Russians claimed to have intruded little into the institu-

6 City commandant to the Syr-Darya provincial chancellery, 23.07.1898, TsGARUz, f. I-17, op. 1, d. 6366, l. $33-34$ ob.

7 Ibid., 400 . 
tions that they found there. They entirely overhauled the local system of justice, according to which the application of sharīa depended on the Muslim royal court and its representatives ( $q \bar{a}$ di $\bar{i}$ included). The Russian policy of the rule of law was designed to draw Muslim subjects nearer to the imperial legal culture so that they would come eventually to prefer Russian law courts to the institutions applying sharîa and imperial law would replace Islamic law. Russian rule represented a typical colonial enterprise, driven as it was by a civilizing mission. The colonial administration never accomplished the project to shut down the "native courts" in Russian Turkestan, and it was not until the Soviets took power that sharîa disappeared from the local juridical field, in the 1920s. The deferral of this project, however, did not harm Russian imperialism. Muslim subjects learned to avail themselves of the new institutional arrangements offered by the colony: a constellation of legal venues to which they could bring their affairs and a cohort of bureaucrats eager to listen to and back up Muslims' complaints, actual or ostensible. Involved as they were in everyday conversations with Russian officials, Muslims accustomed themselves to a legal culture in which new institutions and new notions of justice mattered greatly in the pursuit of their own interests. Women like Nāzira Bībì learned that widows had the right to become the guardians of their underage children and thus dispose of their wealth. This situation would have been unimaginable just a few years before Nāzira Bībī filed her claims with the colonial administration, because the powers of guardians were the prerogatives of senior male members of the family or of the $q \bar{a} d \bar{\imath} \mathrm{s}$. It is also likely that pastoralists like the residents of Jalayir (whom we encountered in Chapter 3 ) would come to know that documentation of land ownership was the key to safeguarding their access to pastures. This was another important innovation, because, before Russian rule, local knowledge was enough to avoid or resolve conflicts over land. Hence, the three Uzbek khanates did not develop cadastration, at least not in the way in which we know cadasters in the West. Others, like Mayram Bībì (Chapter 2) and Ḥāmida Bībī (Chapter 5), understood that they could, with a fatwa, gain the trust of the Russian administrators and play it against their enemies in court. It is unlikely that, before Russian colonization, Muslims brandished legal opinions in asking that a royal court uphold a specific point of law.

Did all these historical actors just play along, or did such legal practices ultimately change their understanding of justice, their ideas of right and wrong? Experiences such as those of Nāzira Bībī and Hāmida Bībì must have played an important role in changing perceptions about law. In other words, I am inclined to believe that they and other women must have learned to think that it was right, for example, for them to claim guardianship over their underage 
children, and they probably understood as wrong and unjust a $q \bar{a} d \underline{\imath} \vec{s}$ disposition of the assets of their children. This is crucial to understand, as we consider how a culture changes over time. If Nāẓira Bībī and Ḥāmida Bībī interiorized Russian notions of guardianship, can we still regard what they said about and did with law as anything specific to "Muslim culture" or "Islam"? Or do they exemplify, as I argued in the Introduction, the ordinariness of an experience of cultural change?

A few years ago, I devoted to the notion of "Muslimness" some space in the introduction to a thematic issue of a journal that was dedicated to the study of Islam in the interwar Soviet Union. ${ }^{8}$ In it, I called for the adoption of a bottomup study of the history of Muslim communities in the Soviet Union. Key to my approach was the notion of "Muslimness," which, I suggested, was the category that could best render the conviction that, "by belonging to a religious and ethical community, Soviet Muslims shared a specific cultural experience." At that time I was reading Bruce Privatsky's excellent ethnographic study of Muslim communities in southern Kazakhstan. During his fieldwork in the town of Turkestan, a place famous in Central Asia as home to the shrine of Ahmad Yasawi and important as a hub of Muslim pilgrimage, Privatsky noted the use of the term musulmanshilı among his interviewees to denote, "an ideology and a preference for Muslim life as an experience of the community ... the religious life of the people, including the elders but not excluding anyone except those "who have gone over to the Russians."

In that essay, I outlined my approach to the study of Muslimness by indicating a few ways in which one could disentangle Muslims' "specific cultural experience" from the historical texture and the epistemic embeddedness of the available sources. I pointed to several phenomena in which Muslimness manifested itself: the transmission of traditional patterns of Islamic education that survived the Stalin period; forms of religiosity in the observance of mourning rituals and healing practices; and the cultivation of Islamic ethics through literary gatherings. In advocating this approach, I relied on previous studies that had demonstrated "the reflexive attitudes of Soviet Muslims towards their religion and towards Islam as a culture."10 In those years, I was an avid reader of the ethnography produced by a group of anthropologists based in Halle

8 P. Sartori, “Towards a History of the Muslims' Soviet Union: A View from Central Asia," WDI 50/3-4 (2010): 315-34 (here 322-25).

9 B.G. Privratsky, Muslim Turkistan: Kazak Religion and Collective Memory (Richmond, Surrey: Curzon, 2001): 78 .

10 J. Rasanayagam, "Introduction." CAS 25/3 (2006): 224. 
(Germany), who were studying the manifestations of religiosity in post-Soviet Central Asia.

Recently I have come to realize that, in employing this concept of "Muslimness," I was not being as original as I had thought. Several other students of Central Asia have written on the subject, frequently adopting what, at the beginning of this book, I termed an "emic perspective." This would allow me, I thought, to complicate the readily available narratives about Islam in Soviet Central Asia and see aspects of Soviet Muslims' experience and subjectivity that one normally does not see. My belief grew stronger when I noticed that anthropologists Johan Rasanayagam and Sergei Abashin had joined in the same venture, though with a focus on different periods and each with his distinctive approach and style, Rasanayagam writing about Muslim Uzbeks in the post-independence period ${ }^{11}$ and Abashin reflecting on the ethnographic notes that he had taken during his early fieldwork in Tajikistan during the Gorbachev era. ${ }^{12}$

While Rasanayagam conceptualizes the emic perspective in terms of morality, Abashin pushes further the reflection on the meaning of Muslimness by analyzing the Soviet public space. He dissects the speeches delivered at rituals called darveshona and xudoy, in which meals were offered to members of village communities, and reviews the tenor of exchanges between their participants. He reflects on the rhetorical strategies - the "speech acts" —employed by prominent individuals (one a kolkhoz brigade leader and one a religious activist) when addressing their audiences. He reaches the conclusion that:

Muslimness [...] remained the grounding point of their identity and the foundation of their authority and special reputation. This condition gave rise to various techniques of the double game that was supposed to bind the "Soviet" and the "Muslim" together, rather than setting them off against each other. ${ }^{13}$

As I draw this book to an end, and as I pause to reflect on the stories that are assembled therein, I realize that the conception of Muslimness and its underlying implications are not unproblematic. I shall now try to clarify what I mean. What would happen if I were to project the synthesis offered by Abashin onto the material from the tsarist archives on which this book is based? Should I

\footnotetext{
11 J. Rasanayagam, Islam in Post-Soviet Uzbekistan: The Morality of Experience (Cambridge: Cambridge University Press, 2011).

12 "A Prayer for Rain: Practising Being Soviet and Muslim." JIS 25/2 (2014): 178-200.

13 Ibid: 197 .
} 
conclude that the stories that I have related here show that Central Asians, while being consumers of colonial justice, retained a Muslim cultural core, a Muslimness of sorts? Does it mean that Central Asian Muslims, in petitioning the Russian authorities, disguised their Muslimness and only pretended to submit to the epistemic rules of the empire? No: the material I have examined points to a very different conclusion. The very fact of thinking in terms of "Muslimness," "tsaristness," and "Sovietness" recalls categories employed by the state (the Russian Empire and later the Soviet Union) to conceptualize cultural difference and legitimize the coexistence of multiple jurisdictions. Central Asians did not adopt such categories when they took legal action, attempted to assert their rights, and articulated their moral ideals. They did not need to invoke their "Muslimness" as opposed to the "tsaristness" of the Russian bureaucracy when they pursued redress. Why should one disassemble what existed as a whole, enmeshed as it was in the experience of every legal actor? The challenge that this book has attempted to meet is to render the totality of the experience encountered by Central Asians in the colonial juridical field. It was an experience that reflected a system of signification that was not monolithic and cohesive, but fractured, contradictory, and ambivalent. Though such a system was based on the idea of cultural difference, Central Asian Muslims did not view their behavior, the law, or the moral world in which they lived through the prism of any such epistemic distinction.

Is it possible, to paraphrase Foucault, to live as the subject of a state that produces a discourse on difference and, at the same time-as I argue was the case of Central Asians under Russian rule-to ignore the vocabulary of such a discourse? This is a question for experts in the study of reception. Central Asians did not-every time they took legal action and wrote (or had someone write for them) to the Russian authorities-pause to ponder the fact that they were Muslims addressing a handful of unbelievers. They must have known that this was the way they ought to operate if they wanted to achieve certain purposes. Many of the cases featured in this book illustrate the determination with which Muslims often pursued legal action against such cornerstones of Islamic authority as $q \bar{a}$ dịs and waqfs, seeking either to constrain such entities or to eliminate them. The sources give little indication that legal actors felt any obligation to preserve their "Muslimness" vis-à-vis the Russian officials who listened to their stories. There are too many cases initiated by Central Asian Muslims for us to infer that their primary reason for going to court was not to defend Islam and the cultural repertoire that we can call Muslimness. Complaints driven by malice are a case in point. Ultimately, there 
always was a Qobil Bobo or a Mullā Rustam, rather than just a "Muslim," behind the locals who petitioned the colonial administration.

Another theme that runs through this book is the use of the colonial courts and the consumption of justice. Regardless of their gender and the position they occupied in society, Central Asians made effective use of the legal institutions that the empire created for them. Not only did they do so before the Russian conquest, as I have shown in Chapter 1, but Muslims did so elsewhere in the Islamicate world. ${ }^{14}$ People, we are prone to think, tend to regard legal action pragmatically. There is always a utilitarian mind behind a lawsuit, one would say. The work of Daniel Lord Smail encourages us, however, to rethink the way we think of the consumption of justice. Examining material from medieval France, Smail suggests that emotions are an integral part of lawsuits and that, in thirteenth-century Marseille, people went to court to articulate their vision of right and wrong, to express their own moral take on things, regardless of their mere calculations. An altercation might easily turn into a court case simply because a party wanted to air her views, blacken the name of others, and publicize her grievance. ${ }^{15} \mathrm{~A}$ similar impression accrues from many of the cases we have considered in this book. One thinks of the countless cases in which an individual files a complaint for a given amount of money, only to settle for half the sum after an amicable settlement is reached. There is, for example, the case of a homicide in Manghishlaq, in which the brother of the deceased sued three men and claimed blood money. The parties made arrangements for the lawsuit to be heard according to Kazakh customary law. This required the involvement of six arbitrators (bis) who met and required either that the defendants produce four individuals from their own community (chosen by the plaintiff) and have them take an exculpatory oath or that they pay blood money to the plaintiff. The parties met before the Qunghrat governor of Kunya-Urgench, in the Russian protectorate of Khiva. When oath takers declared their willingness to take the exculpatory oath, the plaintiff waived his claim and opted instead for an amicable settlement.

In discussing this case elsewhere, ${ }^{16}$ I wondered whether the plaintiff might have been bluffing when be brought his case to the court. I suggested that he may have found himself unable to support his unjustified claim and, facing

14 L. Pierce, Morality Tales: Law and Gender in the Ottoman Court of Aintab (Berkeley: University of California Press, 2003).

15 D.L. Smail, The Consumption of Justice. Emotions, Publicity, and Legal Culture in Marseille, 1264-1423 (Ithaca: Cornell University Press, 2003).

16 P. Sartori, "Murder in Manghishlaq: Notes on an Instance of Application of Qazaq Customary Law in Khiva (1895)." DI 88/2 (2012): 217-57. 
imminent loss, simply gave up. But there is another possibility: it may have been a deep personal conviction as to the three suspects' guilt that pushed the plaintiff to publicize the homicide and forge ahead blindly with the lawsuit, against all odds. The Manghishlaq murder case reminds us that decisions to take legal action are not always rational but may also reflect a cognitive process informed by a moral imaginary comprising ideals, beliefs, and hopes. By examining Central Asians' consciousness of the law under Russian rule, I have tried to show that such a moral imaginary is always historically situated, because it is immanent in the experience of the self. For Tīnīq Ây, the Kazakh woman whom we encountered in Chapter 2 as she attempted to draw the attention of the Russian authorities to the murder of her baby child, to concoct a false accusation against a native judge would have been an entirely normal course of action. This was what she could, and should, do to be heard by the Russians. Our source does not suggest that, in so doing, she faced any moral dilemma, so I believe that she regarded both petitioning and scapegoating the native judge as legitimate means of publicizing her case and pursuing redress. Changes in consciousness of the law are manifest also in juristic thinking. As he explained the lawfulness of his conduct as a native judge, Muhyī al-Dīn Khwāja brought fatwa collections into conversation with imperial statutory laws. Each intervention, whether prompted by a Kazakh woman or a Tashkent jurist, reflects a new system of signification and thus a new age of possibilities.

As Visions of Justice has addressed the topic of change, we may ask whether Muslims were aware of the cultural change brought about in the Islamic juridical field by colonialism. A half-century or more of examination of colonialism in both imperial history and Islamic studies has produced much scholarship, but it has also yielded many assumptions and narratives about "colonial shari ${ }^{-} a$ " that must be analyzed and refined. One such narrative propounds that sharia $a$ underwent, in the nineteenth century, a process of transformation that led ultimately to what many observers have called a rupture. Such a process is usually interpreted as the outcome of modernization, that is, some sort of inevitable evolution in which the West imposed its legal episteme consisting of a new ethos of codification, different institutional arrangements, and altered sensibilities. We are dealing here with a narrative of irreversible decline, in which sharía was shattered and could not be reassembled.

While many institutional changes in the law are obvious and require that we reflect on them, their reception among Muslims is, at once, one of the most obscure issues in the history of colonial sharia and one of the most important. It is unclear whether Muslims perceived these changes as integral to an experience of total transformation affecting their behavior and morality. It is unclear in part because of the Orientalist view of sharita as a jurist's law - which assumes that the evolution of shari $a$ should be measured against 
the juristic models established during the formative period of Islam-and in part because of the anti-Orientalist Muslim critique that propounded a purist view of the law that suggests that everything colonial is contaminated because it comes from the West. The importance of the issue rests not only on the need to understand colonialism, which was so pervasive in many Muslim societies, but above all on the broader benefits that will result from explaining why the transformation of sharia encountered mostly muted opposition, especially in the countries in which law codes were introduced. In spite of all the cultural changes mentioned in this work, there is no evidence that Central Asian Muslims resisted such legal changes that accompanied colonization.

As we have seen in Chapter 5, for example, the hermeneutic activity of muftis shows a striking continuity with precolonial practices. We could reach the same conclusion after examining other genres crafted in the conservative Islamic legal vocabulary. Most accommodated small innovations. Deeds of sale notarized in a native court, for example, do not speak "colonial" as much as an endowment deed crafted in the People's Republic of Bukhara cannot speak "Bolshevik."17 Such continuities allow us to appreciate that Central Asian Muslims probably did not live colonialism as an experience of cultural change, at least when they brought their affairs to native courts. It is true that $q \bar{a} d \bar{c} \bar{s}^{\prime}$ jurisdiction was substantially restricted and that $q \bar{a}$ dịs suffered open attacks on their authority, but, in Russian Central Asia, the number of $q \bar{a} d \bar{l}$ courts skyrocketed (see Chapter 2). Under Russian rule, there were simply more qā and more muftis, and, ultimately, more cases than had previously been heard "according to sharîa,"18 whatever meaning the legists and the laity conferred on that expression. In colonial Central Asia there was transformation coupled with what we might call unwilling shari-fication.

Finally, one should contemplate the possibility that there were Central Asian subjects of the Russian Empire who encountered the law only as it was applied by qā of exposure to "native courts," themselves a colonial institution. But, in spite of the innovations, Central Asians might regard such courts as perfectly "Islamic," because their output accorded with sharita. Muslims clearly lived through times of cultural change, but they probably did not realize the extent to which such changes affected their consciousness of the law.

17 P. Reichmuth, "Lost in the Revolution: Bukharan waqf and Testimony Documents from the Early Soviet Period." DWI 50/3-4 (2010): 362-96.

18 T. Welsford and N. Tashev, A Catalogue of Arabic-Script Documents from the Samarqand Museum (Samarqand and Istanbul: IICAS, 2012): docs. 557, 566, 597, 601, 605, 627, 639 b. 